\title{
Miscanthus $\times$ Giganteus var. KAMIS as a New Feedstock for Cellulose Nitrates
}

\author{
Anna A. Korchagina ${ }^{a}$, Yulia A. Gismatulina ${ }^{a}$, \\ Vera V. Budaeva*a, Vladimir N. Zolotukhin ${ }^{a}$, \\ Nikolay V. Bychin' ${ }^{b}$ and Gennady V. Sakovicha \\ ${ }^{a}$ Institute for Problems of Chemical \\ and Energetic Technologies SB RAS \\ Biysk, Russian Federation \\ bJSC «Federal Research and Production Center «Altai» \\ Biysk, Russian Federation
}

Abstract. Due to the limited volumes of conventional sources of cellulose (cotton and wood), research centered on producing the most competitive science-driven products - cellulose nitrates from new, domestic, easily renewable feedstocks is extremely relevant. The review of scientific literature corroborates the lack of data on the feasibility to obtain cellulose nitrates from Miscanthus, except for the authors' publications. Here we suggest a tree-like industrial crop, Miscanthus var. KAMIS, growing with an yield of up to $20 \mathrm{t} /$ ha a year on industrial plantations in Kaliningradskaya, Kaluzhskaya and Yaroslavskaya Oblasts and in Primorskiy Krai. A pulp sample derived from Miscanthus var. KAMIS by the nitric-acid process exhibits a high $\alpha$-cellulose content of $96 \%$ and degree of polymerization of 1350 . Under optimum synthesis conditions previously identified for unconventional feedstocks, a cellulose nitrate sample was synthesized by treating the pulp with commercially available mixed acid and had the following functional characteristics: $11.26 \%$ nitrogen content, $52 \mathrm{mPa} \cdot \mathrm{s}$ viscosity, and - $95 \%$ solubility on alcohol-ester mixture. Morphological features of pulp and cellulose nitrate samples were characterized by scanning electron microscopy. IR spectroscopy revealed the presence of functional groups in pulp samples $(3411,2913,1637,1429$, $\left.1369,1317,1161,700-500 \mathrm{~cm}^{-1}\right)$ and cellulose nitrate samples $\left(2553,1642,1276,830,746,680 \mathrm{~cm}^{-}\right.$ ${ }^{1}$ ), which allow those samples to be identified as cellulose and nitrate cellulose esters, respectively. It was found by scanning electron microscopy that the cellulose nitrate sample matches industrial Colloxylines by the onset temperature of decomposition $\left(199^{\circ} \mathrm{C}\right)$ and specific head of decomposition $(8,43 \mathrm{~kJ} / \mathrm{g})$. The practical importance of this study is that we experimentally justify the feasibility to

(C) Siberian Federal University. All rights reserved

This work is licensed under a Creative Commons Attribution-NonCommercial 4.0 International License (CC BY-NC 4.0).

* Corresponding author E-mail address: budaeva@ipcet.ru 
utilize the new, unconventional, domestic, easily renewable feedstock, Miscanthus var. KAMIS, as a precursor of high-quality cellulose nitrates.

Keywords: Miscanthus $\times$ giganteus var. KAMIS, nitric-acid process, pulp, nitration, stabilization, cellulose nitrates.

\title{
Мискантус гигантский сорта «КАМИС»- новое сырье для нитратов целлюлозы
}

\author{
А.А. Корчагина ${ }^{a}$ Ю.А. Гисматулина ${ }^{a}$, В.В. Будаева ${ }^{a}$, \\ В.Н. Золотухин ${ }^{\text {a }}$ Н.В. Бычин ${ }^{\tilde{0}}$, Г.В. Сакович ${ }^{\mathrm{a}}$ \\ ${ }^{a}$ Институт проблем химико-энергетических технологий СО РАН \\ Российская Федерация, Бийск \\ ${ }^{\sigma} \mathrm{AO}$ «Федеральный научно-производственный иентр «Алтай» \\ Российская Федерация, Бийск
}

Аннотация. В связи с ограниченностью объемов традиционных источников целлюлозы (хлопка и древесины) исследования, направленные на получение наиболее конкурентоспособных наукоемких продуктов - нитратов целлюлозы - из нового отечественного нетрадиционного легковозобновляемого сырья, чрезвычайно актуальны. Анализ источников научной информации подтверждает отсутствие данных о возможности получения нитратов целлюлозы из мискантусаза исключениемпубликаций авторов. В данной работев качествеперспективного сырьевого источника предложена древовидная техническая злаковая культура - мискантус гигантский сорта «КАМИС», произрастающий с урожайностью до 20 т/га в год на агропромышленных плантациях в Калининградской, Калужской, Брянской, Ярославской областях и в Приморском крае. Образец технической целлюлозы, выделенный азотнокислым способом из мискантуса сорта «КАМИС», характеризуется высокими значениями массовой доли $\alpha$-целлюлозы - 96 \% и степени полимеризации - 1350. В установленных ранее для нетрадиционного сырья оптимальных условиях синтеза путем обработки технической целлюлозы промышленно доступной серно-азотной кислотной смесью был получен образец нитратов целлюлозы с основными функциональными свойствами: массовая доля азота $11,26 \%$, вязкость 52 мПа с, растворимость в спиртоэфирной смеси $95 \%$. Методом растровой электронной микроскопии охарактеризованы морфологические особенности образцов технической целлюлозы и нитратов целлюлозы. Методом ИК-спектроскопии выявлено наличие основных функциональных групп в образцах технической целлюлозы $(3411,2913,1637$, $\left.1429,1369,1317,1161,700-500 \mathrm{~cm}^{-1}\right)$ и нитратов целлюлозы $\left(2553,1642,1276,830,746,680 \mathrm{~cm}^{-1}\right)$, 
позволяющих идентифицировать их как целлюлозу и азотнокислые эфиры целлюлозы соответственно. Методом дифференциальной сканирующей калориметрии установлено, что по температуре начала интенсивного разложения $\left(199{ }^{\circ} \mathrm{C}\right)$ и удельной теплоте разложения (8,43 кДж/г) образец нитратов целлюлозы соответствует промышленным коллоксилинам. Практическая значимость работы заключается в экспериментальном обосновании возможности использования нового отечественного нетрадиционного легковозобновляемого сырья - мискантуса сорта «КАМИС» в качестве прекурсора нитратов целлюлозы высокого качества.

Ключевые слова: мискантус Miscanthus Giganteus сорта «КАМИС», азотнокислый способ, техническая целлюлоза, нитрование, стабилизация, нитраты целлюлозы.

Цитирование: Корчагина, А.А. Мискантус гигантский сорта «КАМИС» - новое сырье для нитратов целлюлозы / А.А. Корчагина, Ю.А. Гисматулина, В.В. Будаева, В.Н. Золотухин, Н.В. Бычин, Г.В. Сакович // Журн. Сиб. федер. унта. Химия, 2020. 13(4). С. 565-577. DOI: 10.17516/1998-2836-0206

\section{Введение}

В современных условиях рыночной экономики ввиду ограниченного объема традиционных источников высококачественной целлюлозы (хлопка и древесины), предназначенной для изготовления широкого спектра продуктов функционального назначения, в качестве первоочередной задачи стоит проблема поиска новых легковозобновляемых сырьевых источников, использование которых позволит сократить зависимость отечественных производителей от импорта.

Самым конкурентоспособным продуктом из сложных эфиров целлюлозы являются нитраты целлюлозы (НЦ), прочно зарекомендовавшие себя в качестве высокополимерной основы твердых ракетных топлив для двигателей и порохов для метательных зарядов ствольных систем [1-5]. Благодаря своим уникальным свойствам, применение НЦ не ограничивается только одной оборонной отраслью, что подтверждается возможностью использования НЦ для изготовления многообразия продуктов мирного назначения (целлулоида, нитролаков, нитроэмалей), а также современной наукоемкой продукции: фильтровальных мембран, селективных сорбентов, специальных лаков для склейки изделий электровакуумной промышленности и др. [6-8].

В настоящее время для получения высококачественной целлюлозы, предназначенной для последующей химической трансформации в НЦ, особое внимание уделяется альтернативным легковозобновляемым источникам сырья. Мировыми исследователями в качестве такой альтернативы рассматриваются: плодовые оболочки овса [9-13], мискантус сахароцветковый сорта Сорановский [12-16], лен-долгунец [17-19], пенька [17, 19], бурые водоросли [20], солома льна-межеумка [21], трава Эспарто [22], древесные опилки [23], бактериальная целлюлоза [24-26].

Для стабильного функционирования и обеспечения независимости рынка производителей НЦ от импорта необходимо развитие собственной промышленной базы на основе отечественного нетрадиционного легковозобновляемого сырья. Анализ источников научной информации

$$
-567-
$$


подтверждает отсутствие данных о возможности получения НЦ из мискантуса за исключением публикаций авторов (мискантус сахароцветковый сорта Сорановский) [12-16]. Мискантус гигантский (М) сорта «КАМИС» зарегистрирован в Российском реестре селекционных достижений и допущен к использованию как многолетняя техническая злаковая культура. Данный сорт М представляет собой растение высотой до 3 м, размножается корневищами и характеризуется высокой продуктивностью, в частности выход биомассы со 2-3 года высадки плантации в среднем составляет 18-20 т/га в год на агропромышленных плантациях в Калининградской, Калужской, Брянской, Ярославской областях и в Приморском крае. Для культуры характерна способность расти на почвах, непригодных для традиционного земледелия. Содержание целлюлозы в сырье по нашим данным составляет 36-50 \%.

Целью настоящей работы являлось получение технической целлюлозы (ТЦ) из М сорта «КАМИС» с последующим синтезом в НЦ, определение показателей качества ТЦ, основных функциональных и физико-химических свойств НЦ, изучение структурных особенностей ТЦ и НЦ.

\section{Материалы и методы}

В представленной работе в качестве исходного сырья для получения ТЦ и ее дальнейшей химической трансформации в НЦ был использован М (Miscanthus Giganteus) сорта «КАМИС» (рис. 1a), выращенный в Московской области (пос. Кокошкино), посадка плантации 2017 г., сбор урожая в феврале 2019 г., поставщик ООО «Мастер Брэнд» (г. Москва). Для получения образца ТЦ использовали все растение (рис. 1б). Процесс азотнокислой варки проводили в лабораторных условиях путем последовательной обработки предварительно измельченного до размера частиц 10-15 мм исходного сырья разбавленными растворами азотной кислоты и гидроксида натрия [14-16, 21]. Фотография образца ТЦ из М сорта «КАМИС» приведена на рис. 1в. Показатели качества образца ТЦ (табл. 1) были определены по стандартным методикам анализа целлюлозы [27].

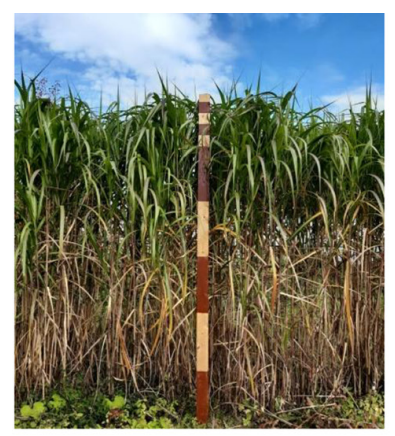

a

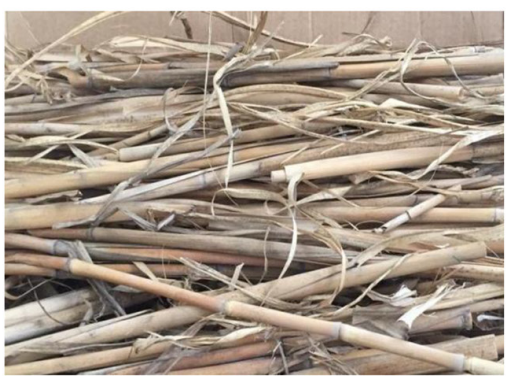

6

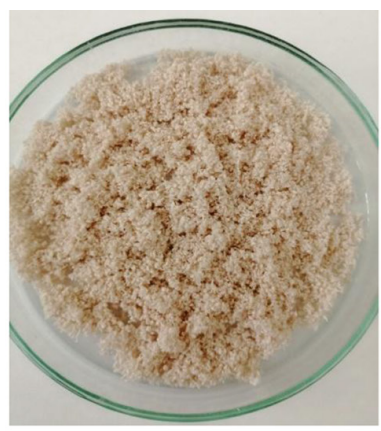

B

Рис. 1. Фотографии: а - М сорта «КАМИС» на плантации; б - исходное сырье М сорта «КАМИС» до измельчения для получения ТЦ; в - образец ТЦ, выделенный азотнокислым способом из М сорта «КАМИС»

Fig. 1. Photographs: a - Miscanthus var. KAMIS on plantation; $\sigma$ - Miscanthus var. KAMIS feedstock prior to grinding to obtain pulp; в - pulp sample derived from Miscanthus var. KAMIS by the nitric-acid method 
Таблица 1. Показатели качества образца ТЦ, выделенного азотнокислым способом из М сорта «КАМИС» Table 1. Quality attributes of pulp sample obtained by the nitric-acid method from Miscanthus var. KAMIS

\begin{tabular}{|c|c|c|c|c|c|}
\hline \multirow{2}{*}{ Наименование образца } & \multicolumn{3}{|c|}{ м.д.*, \% } & \multirow{2}{*}{ СП } \\
\cline { 2 - 6 } & $\alpha$-целлюлозы & золы & $\begin{array}{c}\text { кислотонерастворимого } \\
\text { лигнина }\end{array}$ & пентозанов & 1350 \\
\hline ТЦ из М сорта «КАМИС» & $96,0 \pm 0,5$ & $0,19 \pm 0,05$ & $1,19 \pm 0,05$ & $1,94 \pm 0,05$ & 1305 \\
\hline
\end{tabular}

Примечание: * - массовая доля в пересчете на абсолютно сухое сырье (а.с.с.).

Для получения НЦ образец ТЦ был предварительно высушен до влажности не более 5 \%. Нитрование образца ТЦ проводили по общепринятому сернокислотному способу с использованием промышленно доступной серно-азотной кислотной смеси в следующих условиях: температура 25-30 ${ }^{\circ} \mathrm{C}$, продолжительность 40 мин, модуль 1:25 [9-13]. По окончании процесса нитрования образец НЦ был отжат от адсорбированных кислот и промыт до нейтральной реакции промывных вод, после чего подвергнут высокотемпературной стабилизации в кислой, щелочной и нейтральной средах. Основные функциональные свойства предварительно высушенного в сушильном шкафу при температуре $(100 \pm 5){ }^{\circ} \mathrm{C}$ образца НЦ были определены согласно [9-11]. Массовую долю (м.д.) азота в образце НЦ определяли ферросульфатным способом [28], который основан на омылении образца НЦ концентрированной серной кислотой и восстановлении образовавшейся азотной кислоты сульфатом железа (II) до оксида азота (II), которая с избытком последнего образует комплексное соединение $[\mathrm{Fe}(\mathrm{NO})] \mathrm{SO}_{4}$, окрашивающее раствор в желтовато-розовый цвет. Вязкость образца НЦ устанавливали путем измерения времени истечения 2\%-ного ацетонового раствора из капиллярного стеклянного вискозиметра (ВПЖ-1). Растворимость образца НЦ определяли по методу, основанному на растворении НЦ в спиртоэфирном растворителе при объемном соотношении этилового спирта к диэтиловому эфиру, равном 1:2, с последующей фильтрацией, сушкой и взвешиванием нерастворившегося остатка. Массовую долю золы выявляли по методу, заключающемуся в медленном разложении НЦ концентрированной азотной кислотой при нагревании, с последующим сжиганием и взвешиванием прокаленного остатка. Выход полученного образца НЦ рассчитывали по формуле $\mathrm{W}=\left(\mathrm{m}_{\text {пр }} \times 100\right) / \mathrm{m}_{\text {исх }}$, где $\mathrm{m}_{\text {пр }}-$ масса синтезированного образца НЦ, г; $\mathrm{m}_{\text {исх }}-$ масса исходного образца ТЦ для нитрования, г.

Образцы ТЦ и НЦ были исследованы методом растровой электронной микроскопии (РЭМ) с помощью сканирующего электронного микроскопа JEOLGSM 840 (Япония). На образцы, приклеенные электропроводящим клеем к предметному столику микроскопа, предварительно напыляли Ag методом вакуумного напыления. Толщина слоя Ag 1-5 нм. Режимы работы микроскопа: ускоряющее напряжение $\mathrm{U}_{\text {уск }}=10 \mathrm{\kappa B}$, ток зонда микроскопа $\mathrm{I}_{\text {зонда }}=6 \times 10^{-10} \mathrm{~A}$, рабочее расстояние $\mathrm{W}_{\mathrm{d}}=39$ мм. Образцы исследовали в диапазоне увеличений от $\times 100$ до $\times 10000$ раз. Информация о молекулярной структуре образцов ТЦ и НЦ была получена методом ИК-Фурьеспектроскопии. Регистрацию ИК-спектров проводили на спектрометре «Инфралюм-801» (Россия) в диапазоне частот 4000-500 cм-1. Для съемки ИК-спектров были запрессованы таблетки в бромиде калия в соотношении ТЦ/НЦ: $\mathrm{KBr}=1 / 1: 150$. Исследование образца НЦ методом дифференциальной сканирующей калориметрии проводили с использованием модульного термо-

$$
-569-
$$


анализатора «Mettler Toledo» DSC822 (Швейцария) в условиях: скорость нагрева $20{ }^{\circ} \mathrm{C} / \mathrm{Mин}$, максимальная температура $350^{\circ} \mathrm{C}$, среда инертная - азот.

Работы, выполненные по выделению ТЦ, определению показателей качества ТЦ, нитрованию ТЦ, определению основных функциональных и физико-химических свойств, а также структурных особенностей ТЦ и НЦ проводили с помощью приборной базы Бийского регионального центра коллективного пользования СО РАН (ИПХЭТ СО РАН, г. Бийск).

\section{Обсуждение результатов}

Известно, что получение высококачественных НЦ и изделий на их основе гарантируется только в том случае, если исходная целлюлоза наряду с высокими показателями качества [18, 29] обладает морфологической однородностью, которая оценивается видом целлюлозных волокон, особенностями их структуры, размера, формы, а также наличием включений нецеллюлозного характера [20, 22, 30].

Согласно рис. 1а злаковая культура М сорта «КАМИС» представляет собой высокое растение (около 290 см) в виде прямостоячего куста с толстыми стеблями светло-коричневого цвета и длинными широкими с продольными полосами зелеными листьями. Исходное сырье (рис. 1б), полученное из М сорта «КАМИС», до измельчения для получения ТЦ представляет собой прочные стебли с остатками листьев соломенного цвета. Образец ТЦ (рис. 1в), выделенный из М сорта «КАМИС», предварительно высушенный и подготовленный к нитрованию, представлен в виде однородной рыхлой массы светло-серого цвета без посторонних включений.

Среди альтернативных способов получения целлюлозы [31-33] для выделения целлюлозы из отечественного нетрадиционного легковозобновляемого сырья, в частности М сорта «КАМИС», нами был выбран азотнокислый способ [14-16, 21], который благодаря высокой реакционной способности применяемых в процессе делигнификации разбавленных растворов кислоты и щелочи обеспечивает высокое качество ТЦ, несмотря на природную исключительность исходного сырья. Согласно данным, представленным в табл. 1, образец ТЦ из М сорта «КАМИС» характеризуется высокими значениями м.д. $\alpha$-целлюлозы - $96 \%$ и степени полимеризации - 1350, немного уступая по суммарному значению нецеллюлозных компонентов - 3,32 \%, традиционно используемым для синтеза НЦ целлюлозам из хлопка и древесины $[18,29]$. Сравнивая полученные показатели качества образца ТЦ со свойствами традиционных целлюлоз, можно прогнозировать успешную химическую трансформацию образца ТЦ из М сорта «КАМИС» в НЦ высокого качества.

В табл. 2 представлены основные функциональные свойства и выход образца НЦ из ТЦ М сорта «КАМИС». Согласно данным, представленным в табл. 2, синтезированный образец НЦ из ТЦ М сорта «КАМИС» по функциональным свойствам: м.д. азота - 11,26 \% и растворимости в спиртоэфирной смеси - 95 \% сопоставим со свойствами НЦ из М сахароцветкового сорта Сорановский [12-16]. По значению показателя вязкости - 52 мПа·с образец НЦ из ТЦ М сорта «КАМИС» превосходит НЦ, синтезированные из М сахароцветкового сорта Сорановский. Варьирование основных параметров высокотемпературной обработки НЦ в автоклаве позволит снизить значение показателя вязкости до требуемой нормы [9]. Крайне низкое значение зольности позволяет отнести полученный продукт нитрования с выходом 156 \% к высококачественным НЦ. 
Таблица 2. Основные функциональные свойства и выход синтезированного образца НЦ из ТЦ М сорта «АМИС»

Table 2. Basic functional properties and yield of CN sample synthesized from Miscanthus var. KAMIS pulp

\begin{tabular}{|c|c|c|c|c|c|}
\hline \multirow[b]{2}{*}{$\begin{array}{c}\text { Наименование } \\
\text { образца }\end{array}$} & \multicolumn{4}{|c|}{ Характеристики } & \multirow[b]{2}{*}{ Выход, \% } \\
\hline & $\begin{array}{c}\text { м.д. } \\
\text { азота, \% }\end{array}$ & $\begin{array}{c}\text { вязкость } 2 \% \text {-ного } \\
\text { раствора в ацетоне, } \\
\text { мПағс }\end{array}$ & $\begin{array}{c}\text { растворимость } \\
\text { в спиртоэфирной } \\
\text { смеси, \% }\end{array}$ & $\begin{array}{c}\text { м.д. } \\
\text { золы, \% }\end{array}$ & \\
\hline НЦ из ТЦ М сорта «КАМИС» & 11,26 & 52 & 95 & 0,13 & 156 \\
\hline
\end{tabular}

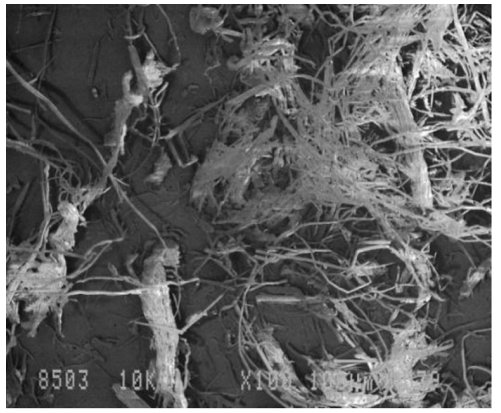

a) $\times 100$

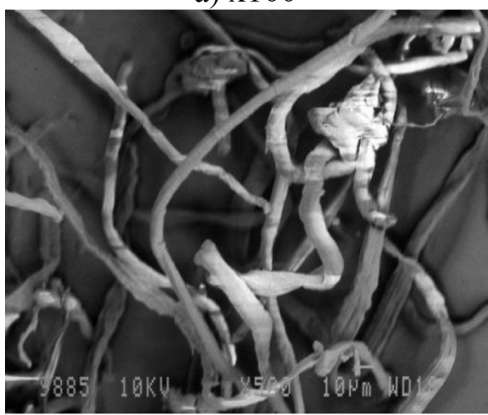

B) $\mathrm{X} 500$

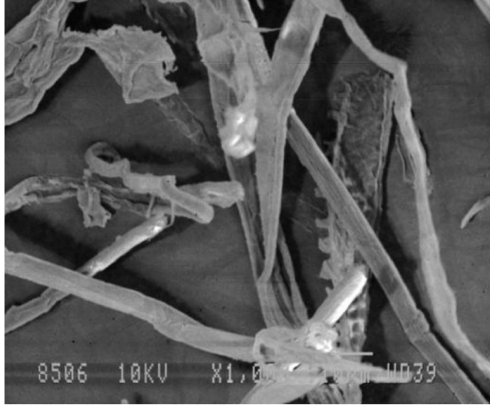

б) $\times 1000$

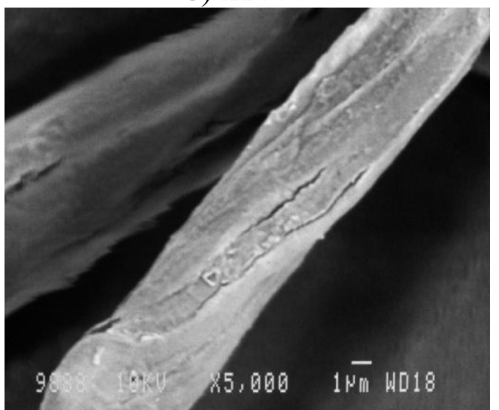

г) $\mathrm{x} 5000$

Рис. 2. Микрофотографии РЭМ образцов: а, б - ТЦ из М сорта «КАМИС»; в, г - НЦ из ТЦ М сорта «КАМИС»

Fig. 2. SEM images of samples: a, б-Miscanthus var. KAMIS pulp; в, г-CN from Miscanthus var. KAMIS pulp

На рис. 2 представлены микрофотографии РЭМ образцов ТЦ из М сорта «КАМИС» и синтезированного образца НЦ. Электронно-микроскопическое исследование показало, что образец ТЦ, выделенный из М сорта «КАМИС» (рис. 2а, б), представляет собой смесь преимущественно неоднородных трубкообразных волокон диаметром 10-30 мкм, переплетенных в «пучок», некоторые волокна трубкообразной формы изогнуты и перекручены. Также в образце ТЦ присутствуют единичные волокна в виде тонких лент шириной до 40 мкм и толщиной 2-5 мкм, часть плоских волокон имеет перфорированные края. Поверхность волокон преимущественно гладкая. По микрофотографиям РЭМ (рис. 2в, г) видно, что после обработки образца ТЦ из М сорта «КАМИС» серно-азотной кислотной смесью волокна НЦ в основном сохраняют форму волокон исходной целлюлозы. Образец НЦ представлен в виде смеси более однородных по диаметру (20-25 мкм) трубкообразных волокон в сравнении с образцом 
исходной ТЦ. В образце НЦ присутствуют единичные агломераты неправильной формы. Поверхность нитратцеллюлозных волокон преимущественно гладкая, однако при увеличении до х5000 (рис. 2г) на поверхности отдельных волокон можно увидеть наличие микротрещин, что может быть обусловлено окислительно-деструктивным действием серно-азотной кислотной смеси.

В результате исследования образца ТЦ из М сорта «КАМИС» методом ИК-Фурьеспектроскопии (рис. 3а) было выявлено, что в ИК-спектре образца ТЦ зарегистрированы основные функциональные группы (3411, 2913, 1637, 1429, 1369, 1317, 1161, 700-500 см-1), характерные для целлюлоз, выделенных из хлопка и древесины $[20,22,34,35]$. После обработки образца ТЦ серно-азотной кислотной смесью в ИК-спектре НЦ (рис. 3б) были обнаружены основные

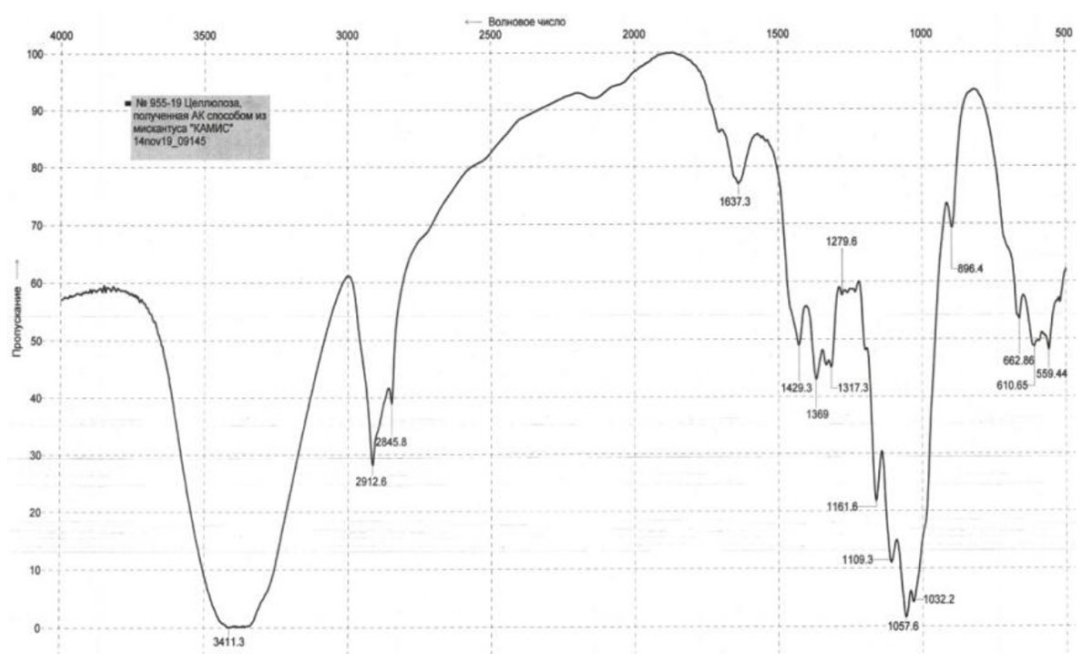

a

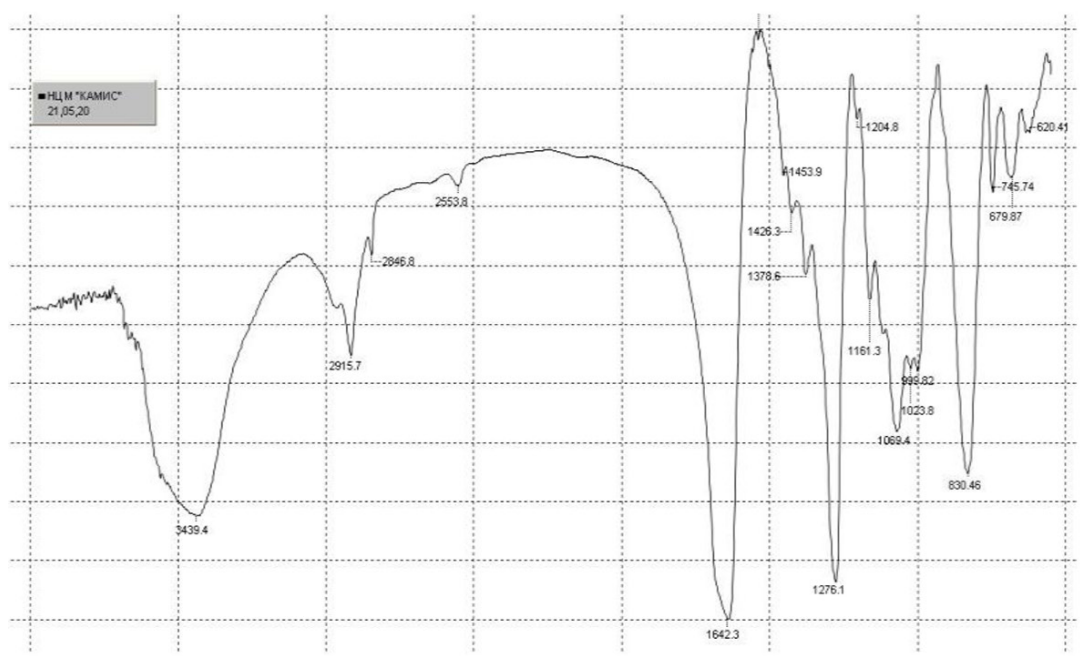

б

Рис. 3. ИК-спектры образцов: а - ТЦ из М сорта «КАМИС»; б - НЦ из ТЦ М сорта «КАМИС»

Fig. 3. IR spectra of samples: a-Miscanthus var. KAMIS pulp; $\sigma-\mathrm{CN}$ from Miscanthus var. KAMIS pulp 


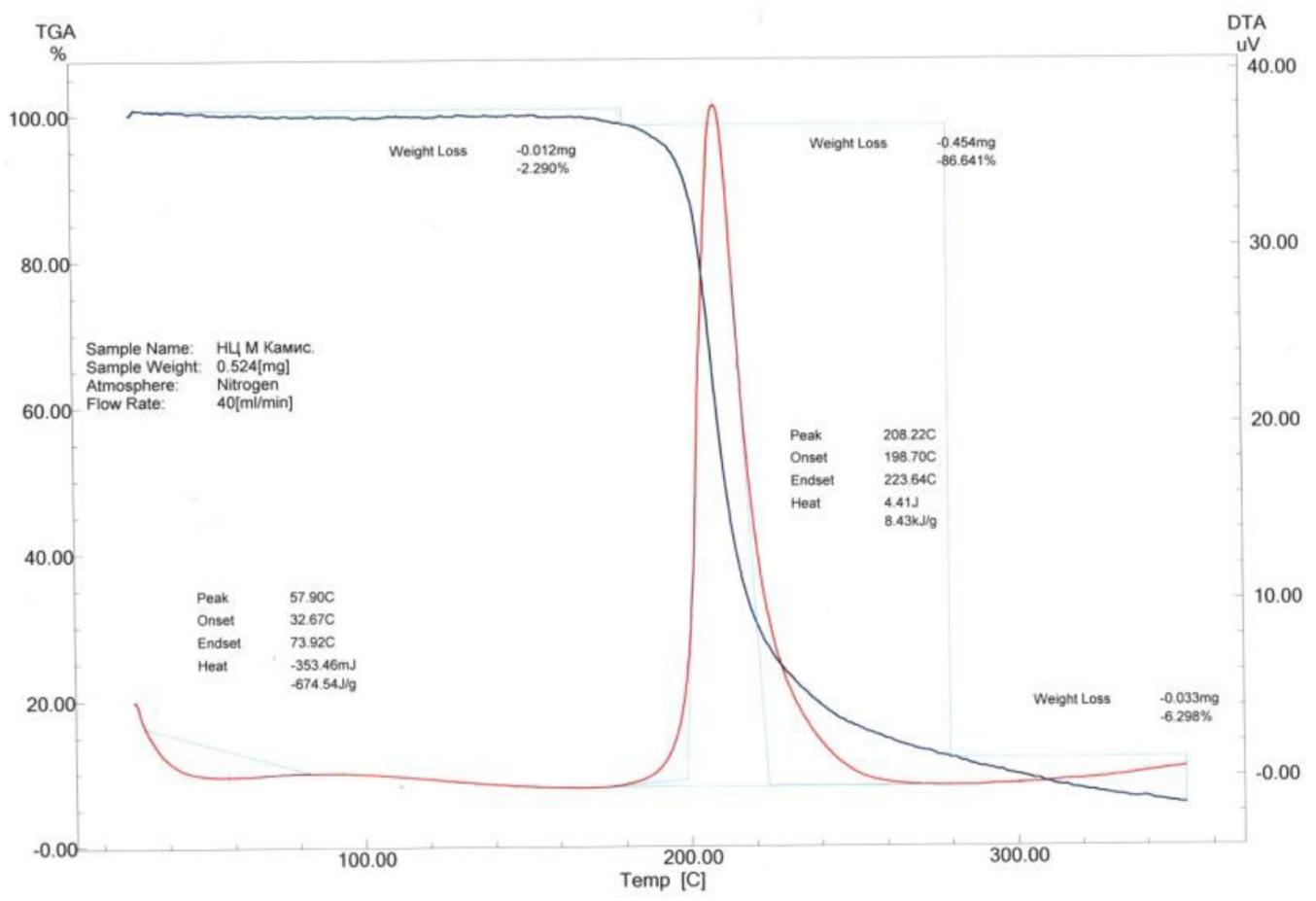

Рис. 4. Результаты термогравиметрического и дифференциально-сканирующего анализов образца НЦ из ТЦ М сорта «КАМИС»

Fig. 4. TGA and DSC data for CN from Miscanthus var. KAMIS pulp

функциональные группы $\left(2553,1642,1276,830,746,680\right.$ см$\left.^{-1}\right)$, позволяющие идентифицировать синтезированный продукт как азотнокислый эфир целлюлозы [20, 22, 34, 35]. Кроме того, в ИКспектре образца НЦ (рис. 3б) в области 3700-3200 см-1 содержатся пики валентных колебаний $v(\mathrm{OH})$ в виде широкой полосы сложного контура, что свидетельствует о неполном замещении НЦ. Пики валентных колебаний в данной области принадлежат гидроксильным группам НЦ, участвующим в образовании водородных связей, и являются характерным признаком химической неоднородности сложного эфира [22].

На рис. 4 представлены результаты исследований синтезированного образца НЦ методом дифференциальной сканирующей калориметрии. В результате проведенных исследований было выявлено, что для образца НЦ из ТЦ М сорта «КАМИС» характерен один узкий экзотермический пик при температуре $208{ }^{\circ} \mathrm{C}$, который сопровождается уменьшением массы образца до 85 \%. Температура начала интенсивного разложения образца НЦ составила $199{ }^{\circ} \mathrm{C}$ $[20,22,34,35]$. Кроме того, образец НЦ характеризуется повышенной удельной теплотой разложения - 8,43 кДж/г, что указывает на практическое отсутствие низконитрованных примесей в продукте этерификации.

\section{Выводы}

Из нового отечественного нетрадиционного легковозобновляемого источника - мискантуса сорта «КАМИС» азотнокислым способом выделен образец ТЦ, характеризующийся вы- 
сокими показателями качества: м.д. $\alpha$-целлюлозы - 96 \% и степени полимеризации - 1350 . В установленных для нетрадиционного сырья оптимальных условиях нитрования синтезирован образец НЦ, который по функциональным свойствам: м.д. азота - 11,26 \% и растворимости в спиртоэфирной смеси - 95 \% сопоставим со свойствами НЦ из мискантуса сахароцветкового сорта Сорановский. Методом РЭМ охарактеризованы морфологические особенности образцов ТЦ из М сорта «КАМИС» и НЦ. Обнаружено, что ТЦ из М сорта «КАМИС» представляет собой преимущественно смесь переплетенных в «пучок» неоднородных трубкообразных волокон, диаметр которых варьируется от от 10 мкм до 30 мкм. После обработки ТЦ серно-азотной кислотной смесью волокна НЦ сохраняют форму волокон исходной целлюлозы, однако трубкообразные волокна НЦ более однородны по диаметру (20-25 мкм). Методом ИК-спектроскопии установлено соответствие образцов ТЦ из М сорта «КАМИС» $(3411,2913,1637,1429,1369,1317$, $\left.1161,700-500 \mathrm{~cm}^{-1}\right)$ и НЦ $\left(2553,1642,1276,830,746,680 \mathrm{~cm}^{-1}\right)$ по основным функциональным группам целлюлозе и азотнокислым эфирам целлюлозы соответственно. Методом дифференциальной сканирующей калориметрии показана высокая чистота синтезированного образца НЦ из ТЦ М сорта «КАМИС» (температура начала интенсивного разложения $199{ }^{\circ} \mathrm{C}$; удельная теплота разложения 8,43 кДж/г).

Таким образом, экспериментально обосновано использование нового отечественного нетрадиционного легковозобновляемого сырья - мискантуса сорта «КАМИС» в качестве прекурсора нитратов целлюлозы высокого качества.

\section{Благодарности / Acknowledgements}

Исследование выполнено при финансовой поддержке РФФИ в рамках научного проекта № 20-03-00699.

The study was carried out with the financial support of the Russian Foundation for Basic Research within the framework of scientific project No. 20-03-00699.

\section{Список литературы / References}

1. Meng X., Pu C., Cui P., Xiao Z. Preparation, thermal and sensitivity properties of nanosized spherical nitrocellulose composite crystal. Propellants, Explosives, Pyrotechnics 2020. Vol. 45, P. 1-11.

2. Rodrigues R.L.B., Lemos M.F., França T.C.C., Mendonça Filho L.G. Development of nitrocellulose-based propellants with natural stabilizers. J. Aerosp. Technol. Manag., São José dos Campos, Special Edition 2019. Vol. 11, P. 3-6.

3. Shen J., Liu Z., Xu B., Liang H., Liao X., Wang Z. Influence of carbon nanofibers on thermal and mechanical properties of NC-TEGDN-RDX triple-base gun propellants. Propellants, Explosives, Pyrotechnics 2019. Vol. 44(3), P. 355-361.

4. Heil M., Hickmann J., Müller C. Thermal characterization of naturally aged propellants. Propellants, Explosives, Pyrotechnics 2019. Vol. 44(6), P. 687-695.

5. Романова С.М., Фатыхова Л.А. Химия азотнокислых эфиров целлюлозы. Журнал Сибирского федерального университета. Химия 2014. T. 7(1), С. 151-158. [Romanova S.M., Fatykhova L.A. Chemistry of nitrate cellulose ethers. Journal of Siberian Federal University. Chemistry 2014. Vol. 7(1), P. 151-158 (In Russ.)]. 
6. Fernández J.G., Almeida C.A., Fernández-Baldo M.A., Felici E., Raba J., Sanz M.I. Development of nitrocellulose membrane filters impregnated with different biosynthesized silver nanoparticles applied to water purification. Talanta 2016. Vol. 146, P. 237-243.

7. Olcay A.N., Polat M., Polat H. Ancillary effects of surfactants on filtration of low molecular weight contaminants through cellulose nitrate membrane filters. Colloids and Surfaces A: Physicochem. Eng. Aspects 2016. Vol. 492. P. 199-206.

8. Романова С.М., Павлова Д.И., Мадякина А.М., Хузеев М.В. Реакции нитратов целлюлозы с гетероциклическими соединениями. Журнал Сибирского федерального университета. Химия 2015. T. 8(3), C. 336-345. [Romanova S.M., Pavlova D.I., Madyakina A.M., Khuzeev M.V. The reactions between cellulose nitrate and heterocyclic compounds. Journal of Siberian Federal University. Chemistry 2015. Vol. 8(3), P. 336-345 (In Russ.)].

9. Korchagina A.A., Gismatulina Yu.A., Budaeva V.V., Kukhlenko A.A., Vdovina N.P., Ivanov P.P. Autoclaving cellulose nitrates obtained from fruit shells of oats. Izv. Vyssh. Uchebn. Zaved. Khim. Khim. Tekhnol. [Russ. J. Chem. \& Chem. Tech.] 2020. Vol. 63(1), P. 92-98.

10. Korchagina A.A., Budaeva V.V., Kukhlenko A.A. Esterification of oat-hull cellulose. Russian Chemical Bulletin, International Edition 2019. Vol. 68(6), P. 1282-1288.

11. Sakovich G.V., Budaeva V.V., Korchagina A.A., Gismatulina Yu.A., Kozyrev N.V., Vakutin A.G. Oat-hull cellulose nitrates for explosive compositions. Doklady Chemistry 2019. Vol. 487(2), P. 221-225.

12. Сакович Г.В., Будаева В.В., Корчагина А.А., Гисматулина Ю.А. Перспективы нитратов целлюлозы из нетрадиционного сырья для взрывчатых составов. Химия растительного сырья 2019. № 1, C. 259-268. [Sakovich G.V., Budaeva V.V., Korchagina A.A., Gismatulina Yu.A. Prospects of cellulose nitrates from unconventional feedstocks for use in composite explosives. Khimiya Rastitelnogo Syrya 2019. Vol. 1, P. 259-268. (In Russ.)].

13. Sakovich G.V., Mikhailov Yu.M., Budaeva V.V., Korchagina A.A., Gismatulina Yu.A., Kozyrev N.V. Cellulose nitrates from unconventional feedstocks. Doklady Chemistry 2018. Vol. 483(1), P. 287-291.

14. Gismatulina Yu.A., Budaeva V.V., Sakovich G.V. Nitrocellulose synthesis from Miscanthus cellulose. Propellants, Explosives, Pyrotechnics 2018. Vol. 43, P. 96-100.

15. Gismatulina Yu.A., Budaeva V.V. Chemical composition of five Miscanthus sinensis harvests and nitric-acid cellulose therefrom. Industrial Crops and Products 2017. Vol. 109, P. 227-232.

16. Gismatulina Yu.A., Budaeva V.V., Sakovich G.V. Nitric acid preparation of cellulose from miscanthus as a nitrocellulose precursor. Russian Chemical Bulletin 2015. Vol. 64(12). P. 2949-2953.

17. Golubev A.E., Kuvshinova S.A., Burmistrov V.A., Koifman O.I. Modern advances in the preparation and modification of cellulose nitrates. Russian Journal of General Chemistry 2018. Vol. 88(2). P. 368-381.

18. Лен в пороховой промышленности. Научное издание, доп. и перер. под. ред. С.И. Григорова. М: ФГУП «ЦНИИХМ», 2015. 348 с. [Flax in powder industry. Under Ed. S.I. Grigorov. Moscow, 2015. 348 p. (In Russ.)].

19. Ebskamp M.J.M. Engineering flax and hemp for an alternative to cotton. TRENDS in Biotechnology 2002. Vol. 20(6), P. 229-230.

20. Tarchoun A.F., Trache D., Klapötke T.M., Chelouche S., Derradji M., Bessa W., Mezroua A. A promising energetic polymer from posidonia oceanica Brown Algae: synthesis, characterization, and kinetic modeling. Macromolecular Chemistry and Physics 2019. № 1900358.

$$
-575-
$$


21. Gismatulina Yu.A., Budaeva V.V., Sakovich G.V. Cellulose nitrates from intermediate flax straw. Russian Chemical Bulletin 2016. Vol. 65(12), P. 2920-2924.

22. Trache D., Khimeche K., Mezroua A., Benziane M. Physicochemical properties of microcrystalline nitro-cellulose from alfa grass fibres and its thermal stability. Thermal Analysis and Calorimetry 2016. Vol. 124(3), P. 1485-1496.

23. Adekunle I.M. Production of cellulose nitrate polymer from sawdust. Journal of Chemistry 2010. Vol. 7(3), P. 709-716.

24. Budaeva V.V., Gismatulina Y.A., Mironova G.F., Skiba E.A., Gladysheva E.K., Kashcheyeva E.I., Baibakova O.V., Korchagina A.A., Shavyrkina N.A., Golubev D.S., Bychin N.V., Pavlov I.N., Sakovich G.V. Bacterial Nanocellulose Nitrates. Nanomaterials 2019. Vol. 9(12). № 1694.

25. Сакович Г.В., Скиба Е.А. Гладышева Е.К., Будаева В.В., Алешина Л.А. Химические аспекты БНЦ. Журнал Сибирского федерального университета. Химия 2018. Т. 11(4), С. 531542. [Sakovich G.V., Skiba E.A., Gladysheva E.K., Budaeva V.V., Aleshina L.A. Chemical aspects of bacterial nanocellulose. Journal of Siberian Federal University. Chemistry 2018. Vol. 11(4), P. 531-542 (In Russ.)].

26. Sun D.P., Ma B., Zhu C.L., Liu C.S., Yang J.Z. Novel nitrocellulose made from bacterial cellulose. Journal of Energetic Materials 2010. Vol. 28, P. 85-97.

27. Оболенская А.В., Ельницкая 3.П., Леонович А.А. Лабораторные работы по химии древесины и целлюлозы. М.: Экология, 1991. 320 c. [Obolenskaya A.V., El'nickaya Z.P., Leonovich A.A. Laboratory work on the chemistry of wood and cellulose. Moscow: Ecology, 1991. 320 p. (In Russ.)].

28. Gensh K.V., Kolosov P.V., Bazarnova N.G. Quantitative analysis of cellulose nitrates by Fourier Transform Infrared Spectroscopy. Russian Journal of Bioorganic Chemistry 2011. Vol. 37(7), P. 814-816.

29. Жегров Е.Ф., Милехин Ю.М., Берковская Е.В. Химия и технология баллиститных порохов, твердых ракетных и специальных топлив, в 2 т. Технология, монография; РИЦ МГУП им. И. Федорова: Москва, 2011, т. 2. С. 35-101. [Zhegrov Ye.F., Milekhin Yu.M., Berkovskaya Ye.V. Chemistry and technology of ballistic powders, solid rocket and special fuels. In 2 Vol. Moscow, 2011, Vol. 2. P. 35-101 (In Russ.)].

30. Venkateshaiah A., Padil V.V., Nagalakshmaiah M., Waclawe S., Cerník M., Varma R.S. Microscopic techniques for the analysis of micro and nanostructures of biopolymers and their derivatives. Polymers 2020. Vol. 12(3), Р. 512-544.

31. Гарынцева Н.В., Судакова И.Г., Кузнецов Б.Н. Изучение процесса пероксидной делигнификации древесины сосны в среде уксусная кислота-вода. Журнал Сибирского федерального университета. Химия. 2018. Т. 11(2), C. 291-303. [Garyntseva N.V., Sudakova I.G., Kuznetsov B.N. The study of the process of pine wood peroxide delignification in the medium of acetic acid-water. Journal of Siberian Federal University. Chemistry 2018. Vol. 11(2), P. 291-303. (In Russ.)].

32. Яценкова О.В., Судакова И.Г., Скрипников А.М., Кузнецов Б.Н. Влияние условий пероксидной каталитической делигнификации древесины березы на выход и состав целлюлозных продуктов. Журнал Сибирского федерального университета. Химия 2016. Т. 9(2), С. 188200. [Yatsenkova O.V., Sudakova I.G., Skripnikova A.M., Kuznetsov B.N. The influence of conditions of birch wood peroxide catalytic delignification on the yield and composition of cellulosic products. Journal of Siberian Federal University. Chemistry 2016. Vol. 9(2), P. 188-200. (In Russ.)].

$$
\text { - } 576 \text { - }
$$


33. Левданский В.А., Левданский А.В., Кузнецов Б.Н. Способ получения из льна целлюлозного продукта с высоким содержанием альфа-целлюлозы. Журнал Сибирского федерального университета. Химия 2014. T. 7(1), C. 63-70. [Levdansky V.A., Levdansky A.V., Kuznetsov B.N. Method of obtaining from flax the cellulosic product with high content of alfa-cellulose. Journal of Siberian Federal University. Chemistry 2014. Vol. 7(1), P. 63-70. (In Russ.)].

34. Gao Z., Jiang L., Xu Q., Wub W.Q., Mensah R.A. Thermal kinetics and reactive mechanism of cellulose nitrate decomposition by traditional multi kinetics and modeling calculation under isothermal and non-isothermal conditions. Industrial Crops and Products 2020. Vol. 145. № 112085.

35. Meng X., Pu C., Cu P., Xiao Z. Preparation, thermal and sensitivity properties of nano-sized spherical nitrocellulose composite crystal. Propellants, Explosives, Pyrotechnics 2020. Vol. 45, P. 1-11. 